\title{
Blood profile of obese and aged dogs (Canis familiaris)
}

\section{Christina Resende Martins ${ }^{1}$, Pablo Gomes Noleto ${ }^{2}$, Renata Lima de Miranda ${ }^{3}$, Antonio Vicente Mundim ${ }^{1}$}

\begin{abstract}
${ }^{1}$ Federal University of Uberlândia, School of Veterinary Medicine, Uberlândia, MG, Brazil
${ }^{2}$ Animal and Plant Health Agency, Laboratory of Animal Diagnostic, Goiania, GO, Brazil

${ }^{3}$ Federal University of Uberlândia, Institute of Biomedical Sciences, MG, Brazil
\end{abstract}

Received January 10, 2018

Accepted February 12, 2019

\begin{abstract}
The aim of this study was to evaluate the blood profile and haematological changes in obese adult and senior dogs. An evaluation was made from the blood profile of 59 obese adult and senior dogs. The animals were divided into two groups, group 1 (G1) with 30 obese adult dogs ( 2 to 8 years) and group 2 (G2) with 29 obese senior dogs (over 8 years old). The mean values of the erythrogram and platelet count parameters of both groups remained within the compared reference ranges except the red cell distribution width (RDW), whose values were lower than the reference ranges in both groups. A comparison of the values of erythrogram and platelet count of the groups indicated that the RDW and MPV (mean platelet volume) of G2 were higher than those of G1. As for the white blood cell count (WBC), only the number of band neutrophils exceeded the physiological limits for the species in both groups, with no significant difference in values between the age groups. The males in G2 showed a significantly higher mean eosinophil count than those in G1 and than the females of both groups. As for the frequency of findings, $90 \%$ of the animals in G1 and $68.96 \%$ in G2 showed left shift neutrophils (LSN), while $34.48 \%$ in G1 and $20 \%$ in G2 showed eosinophilia. It was concluded that, irrespective of age, obese animals presented no changes in erythrogram and platelet indices, and that their WBC may exhibit discrete LSN without leukocytosis.
\end{abstract}

Complete blood count, white blood cell count, obesity

Over the years, the relationship between humans and dogs has become increasingly close, transforming the latter from a "pet animal" to a companion or family member. This new relationship has led to a major advance in the development of vaccines, drugs and food specifically for dogs. As a result, their life expectancy has been extended, making the canine population increasingly composed of aged individuals (Figueiredo 2005; Carrijo and Souza 2009).

This close proximity of dog and owner has also lead to changes in the eating habits and general lifestyle of these animals. In the past, the dogs' diet consisted basically of protein and fat, which required great physical effort to obtain. Today, their diet has high contents of carbohydrates, and access to food is much easier. Dog obesity has thus become increasingly common (Kienzle et al. 1998; Lazarotto 1999; Faria et al. 2005).

Obesity is considered the most common nutritional and metabolic disorder in developed countries, and is defined as a pathological disorder characterized by the accumulation of much higher levels of fat than necessary for optimal organic performance (Wolfsheimer 1994). It is estimated that $34.1 \%$ of the Australian canine population is overweight or obese (Mcgreevy et al. 2005). Few studies on this subject have been conducted in Brazil, but a study in the city of São Paulo revealed a prevalence of $16.5 \%$ of obese dogs (Jericó and Scheffer 2002).

Address for correspondence:

Pablo Noleto

Laboratório de Análise e Diagnóstico Veterinário

Rodovia R2 S/No Área/Lote AR4, Campus Samambaia

Goiânia, GO, Brazil, CEP 74.691-886 
Despite extensive research, a unified theory for the development of this disease has not yet been proposed. The main factors that may predispose a dog to excess weight are: breed, sex, age, neutering or spaying, genetic factors, physical activity, and dietary energy density (Kienzle et al. 1998; Markwell and Edney 1996; Carciofi et al. 2005; Diez and Nguyen 2006; German 2006). Middle-aged to senior dogs are more predisposed, and the age range with the highest prevalence of obesity is between 5 and 10 years (Diez and Nguyen 2006; Laflamme 2006).

Adipose tissue has recently been recognized as an active endocrine organ that is able to secrete hormonal and protein factors, collectively known as adipokines (Trayhurn and Beattie 2001; Trayhurn 2005). The wide variety of cytokines, chemokines and other inflammation-related proteins secreted by adipose tissue may cause a mild chronic inflammatory condition in obese humans (Trayhurn and Wood 2004).

A study by German et al. (2009) found that just as in humans, obesity could predispose dogs to a state of subclinical inflammation. This theory appears to be confirmed by the fact that the mean leukocyte count in their experiment was in upper limit of the reference range, decreasing significantly after weight loss.

The adipose tissue produces an amount of pro-inflammatory cytokines, such as tumour necrosis factor- $\alpha$ (TNF- $\alpha$ ) and interleukin-6 (IL-6), which were originally studied for their role on the immune system. The main role of those cytokines is to activate the immune system towards infection or cancer cells. However, overproduction is considered a risk factor to various diseases in humans (Weisberg et al. 2003).

Regardless of the cell type these cytokines stimulate, the adipose tissue is known as an active immunology tissue. It is also known that the increase of TNF- $\alpha$ and IL- 6 occur in the obesity, and that the weight reduction decrease their production. Therefore, obesity represents a light chronic inflammatory condition (Bastard et al. 2006; Inadera 2008).

An experiment conducted by Haris hankar et al.(2011) on obese mice showed that obesity did not lead to significant haematological abnormalities except for thrombocytopenia. The aim of this study was to evaluate the blood profile and haematological changes (erythrogram, platelet count and white blood cell count [WBC]) in obese adult and senior dogs.

\section{Materials and Methods}

This study involved small and medium sized male and female dogs of various breeds (Pug, Poodle, mixed-breed [mongrel], Schnauzer, Yorkshire, Chihuahua, Cocker Spaniel and Dachshund), clinically healthy, living in the city of Uberlândia, MG, Brazil. The animals in this study had a body condition score of 8 to 9 , classified according to the body condition score chart for dogs proposed by Laflamme (1997), which assesses the amount of muscle mass and fat in the ribcage, pelvic bones, spine and ribs by means of body palpation. According to these indicators, animals are classified into five categories ranging from 1 to 9 (very thin, thin, ideal, overweight, and obese). The dogs were divided into two age groups: group 1 (G1), comprising 30 obese dogs between 2 and 8 years old (20 females and 10 males); and group 2 (G2), comprising 29 obese dogs over 8 years old (22 females and 7 males).

The animals' medical information was recorded and they were subjected to clinical examination to determine the rectal temperature, heart rate, and breathing rate; using abdominal palpation, to rule out any clinical disorder or disease; and to understand their habits. Three millilitres of blood were then drawn from each animal by cephalic venipuncture, using a $5 \mathrm{ml}$ disposable scalp vein syringe, between 8:00 and 11:00 h, after $12 \mathrm{~h}$ of fasting. The blood samples were placed in two sterile tubes (one containing 10\% ethylenediaminetetraacetic acid tripotassium salt $\left(\right.$ EDTA $\mathrm{K}_{3}$ ) as anticoagulant, and other containing serum clot activator tube) stored in cool boxes, and immediately sent to the Clinical Laboratory of the Federal University of Uberlândia Veterinary Hospital. In the laboratory, each blood sample was subjected to a haemogram involving haemoglobin, packed cell volume (PCV), red blood cell count (RBC), mean corpuscular volume (MCV), mean corpuscular haemoglobin concentration (MCHC), red cell distribution width (RDW), platelet count, mean platelet volume (MPV), and leukocyte count in an automated cell counter (ABC Vet Animal Blood Counter, Horiba ABX Diagnostics Ltd., São Paulo, SP, Brazil). Differential leukocyte counts were carried out on blood smears stained with May-Grünwald Giemsa by the same valuer in light microscopy (Matos and Matos 1988). The biochemical screening tests performed were: alkaline phosphatase, gamma glutamyltransferase, alanine aminotransferase, glucose, total cholesterol and fractions, triglycerides, urea and creatinine. Animals that presented alterations in any of these indices were excluded from the study. 
The reference values cited by Weiss and Wardrop (2010) and those of the animals of group 1 in the study by Zvorc et al. (2010) were used for comparison.

A completely randomized design was used, and the resulting values were subjected to ANOVA and $t$-test for samples with normal distribution and Mann-Whitney test was used for non-normally distributed samples, both tests at a 5\% level of significance. A multiple comparison test for proportions was performed using the $\mathrm{R}$ statistical program, according to Biase and Ferreira (2009), to compare the frequency of findings in the erythrogram, platelet count and WBC.

This study was conducted according to the ethical principles for animal experimentation established by the National Council for the Control of Animal Experimentation (CONCEA), and was approved by the Ethics Committee on Animal Use (CEUA) of the Federal University of Uberlândia, under Protocol No. 007/12 and Opinion No. 036/12.

\section{Results}

The mean PCV, haemoglobin, RBC, MCV, MCHC, platelet count and MPV in the two groups remained within the compared reference intervals, with no difference between G1 and G2. A comparison of the RDW values of the two groups revealed a lower average than the reference values for the species (Table 1).

Table 1. Values (mean \pm standard deviation) of the erythrogram and platelet count of obese dogs by age group.

\begin{tabular}{|c|c|c|c|c|c|}
\hline \multirow[t]{2}{*}{ Indicator } & \multicolumn{2}{|c|}{$\begin{array}{l}\text { G1 }(30 \text { dogs }) \\
\text { ( } 2 \text { to } 8 \text { years })\end{array}$} & \multicolumn{2}{|c|}{$\begin{array}{c}\text { G2 }(29 \text { dogs }) \\
(>8 \text { years })\end{array}$} & \multirow[t]{2}{*}{$\begin{array}{l}\text { Reference } \\
\text { value }\end{array}$} \\
\hline & Mean & SD & Mean & SD & \\
\hline Haemoglobin (g/dl) & $17.79^{\mathrm{a}}$ & 2.86 & $17.32^{\mathrm{a}}$ & 2.28 & $12-18^{*}$ \\
\hline $\operatorname{PCV}(\%)$ & $53.86^{\mathrm{a}}$ & 7.53 & $51.49^{\mathrm{a}}$ & 7.09 & $37-55^{*}$ \\
\hline $\operatorname{RBC}\left(\times 10^{6} / \mu 1\right)$ & $8.17^{\mathrm{a}}$ & 0.88 & $7.97^{\mathrm{a}}$ & 1.05 & $5.5-8.5^{*}$ \\
\hline $\operatorname{MCV}(f l)$ & $65.90^{\mathrm{a}}$ & 5.59 & $64.83^{\mathrm{a}}$ & 5.61 & $60-77^{*}$ \\
\hline $\mathrm{MCHC}(\mathrm{g} / \mathrm{dl})$ & $33.86^{\mathrm{a}}$ & 1.20 & $33.69^{\mathrm{a}}$ & 1.33 & $32-36^{*}$ \\
\hline RDW (\%) & $13.32^{\mathrm{a}}$ & 0.72 & $13.59^{\mathrm{a}}$ & 0.84 & $13.80-18^{* *}$ \\
\hline $\operatorname{PLT}\left(\times 10^{3} / \mu \mathrm{l}\right)$ & $288.33^{\mathrm{a}}$ & 118.81 & $259.66^{\mathrm{a}}$ & 95.54 & $200-500^{*}$ \\
\hline MPV (fl) & $8.94^{\mathrm{a}}$ & 1.14 & $9.42^{\mathrm{a}}$ & 0.94 & $7.9-13.50^{* *}$ \\
\hline
\end{tabular}

(a,b) Different superscripts in rows indicate a significant difference $(P<0.05)$.

SD - standard deviation; G1 - Group 1; G2 - Group 2; PCV - packed cell volume; RBC - red blood cell count; MCV mean corpuscular volume; MCHC - mean corpuscular haemoglobin concentration; RDW - red blood cell distribution width; PLT - platelet count; MPV - mean platelet volume. *Weiss and Wardrop (2010). **Zvorc et al. (2010).

Comparing the age groups and sexes (Table 2), only the RDW and MPV showed significant differences $(P<0.05)$, with the females of G2 showing a higher average.

A comparison of the indices of the erythrogram of each animal against the reference values (Weiss and Wardrop 2010; Zvorc et al. 2010) revealed that none of the animals showed a reduced haemoglobin count, PCV, and haemocyte count. However, $46.66 \%$ of the dogs in G1 and $41.37 \%$ in G2 presented an increased haemoglobin concentration, 43.34\% in G1 and 31.03\% in G2 showed an increased PCV, and $23.34 \%$ in G1 and $27.59 \%$ in G2 exhibited an augmented haemocyte count (Table 3). A marked reduction was also observed in the value of RDW, with $76.66 \%$ of G1 and $44.82 \%$ of G2 presenting decreased values for this indicator compared to the values reported by Zvorc et al. (2010). As for MPV, $83.34 \%$ of the dogs in G1 and $75.86 \%$ in G2 showed MPV values within the limits of normality, and none of the animals presented any increase in the value of this indicator.

The mean total leukocytes, total neutrophils, segmented neutrophils, monocytes, eosinophils and lymphocytes remained within the compared reference ranges in both groups, with no significant difference between them. Both groups showed mean band neutrophils higher than the compared reference values, also with no difference between G1 and G2 (Table 4). 
Table 2. Values (mean \pm standard deviation) of the erythrogram indicators and platelet count of obese dogs by age group and sex.

\begin{tabular}{|c|c|c|c|c|c|}
\hline \multirow[t]{2}{*}{ Indicator } & \multirow[t]{2}{*}{ Sex } & \multicolumn{2}{|c|}{$\begin{array}{l}\text { G } 1(30 \text { dogs }) \\
\text { (2 to } 8 \text { years })\end{array}$} & \multicolumn{2}{|c|}{$\begin{array}{c}\text { G } 2(29 \text { dogs }) \\
\text { (> } 8 \text { years })\end{array}$} \\
\hline & & Mean & SD & Mean & SD \\
\hline \multirow{2}{*}{ Haemoglobin (g/dl) } & $\mathrm{M}$ & $16.86^{\mathrm{aA}}$ & 3.37 & $17.07^{\mathrm{aA}}$ & 2.77 \\
\hline & $\mathrm{F}$ & $18.25^{\mathrm{aA}}$ & 2.54 & $17.40^{\mathrm{aA}}$ & 2.17 \\
\hline \multirow{2}{*}{ PCV (\%) } & $\mathrm{M}$ & $53.55^{\mathrm{aA}}$ & 6.67 & $50.51^{\mathrm{aA}}$ & 8.05 \\
\hline & $\mathrm{F}$ & $54.02^{\mathrm{aA}}$ & 8.08 & $51.80^{\mathrm{aA}}$ & 6.94 \\
\hline \multirow{2}{*}{$\mathrm{RBC}\left(\times 10^{6} / \mu 1\right)$} & M & $8.10^{\mathrm{aA}}$ & 0.43 & $7.90^{\mathrm{aA}}$ & 1.41 \\
\hline & $\mathrm{F}$ & $8.20^{\mathrm{aA}}$ & 1.05 & $7.99^{\mathrm{aA}}$ & 0.95 \\
\hline \multirow{2}{*}{ MCV (fl) } & $\mathrm{M}$ & $65.90^{\mathrm{aA}}$ & 6.59 & $64.29^{\mathrm{aA}}$ & 3.30 \\
\hline & $\mathrm{F}$ & $65.90^{\mathrm{aA}}$ & 5.20 & $65.00^{\mathrm{aA}}$ & 6.22 \\
\hline \multirow{2}{*}{$\mathrm{MCHC}(\mathrm{g} / \mathrm{dl})$} & M & $34.09^{\mathrm{aA}}$ & 1.34 & $33.81^{\mathrm{aA}}$ & 0.72 \\
\hline & $\mathrm{F}$ & $33.75^{\mathrm{aA}}$ & 1.14 & $33.65^{\mathrm{aA}}$ & 1.49 \\
\hline \multirow{2}{*}{ RDW (\%) } & $\mathrm{M}$ & $13.34^{\mathrm{aA}}$ & 0.89 & $13.96^{\mathrm{aA}}$ & 0.50 \\
\hline & $\mathrm{F}$ & $13.02^{\mathrm{aB}}$ & 0.61 & $13.60^{\mathrm{aA}}$ & 0.91 \\
\hline \multirow{2}{*}{ PLT $\left(\times 10^{3} / \mu 1\right)$} & $\mathrm{M}$ & $269.00^{\mathrm{aA}}$ & 144.45 & $287.86^{\mathrm{aA}}$ & 106.02 \\
\hline & $\mathrm{F}$ & $298.00^{\mathrm{aB}}$ & 106.61 & $250.68^{\mathrm{aA}}$ & 92.79 \\
\hline \multirow{2}{*}{ MPV (fl) } & $\mathrm{M}$ & $9.06^{\mathrm{aA}}$ & 1.35 & $9.54^{\mathrm{aA}}$ & 0.79 \\
\hline & $\mathrm{F}$ & $8.73^{\mathrm{aB}}$ & 1.05 & $9.78^{\mathrm{aA}}$ & 0.99 \\
\hline
\end{tabular}

(A,B) Different upper-case superscript in columns indicate significant difference between age groups $(P<0.05)$.

$(a, b)$ Different lower-case superscripts in rows indicate significant difference between males and females $(P<0.05)$.

SD - standard deviation; G1 - Group 1; G2 - Group 2; PCV - packed cell volume; RBC - red blood cell count; MCV mean corpuscular volume; MCHC - mean corpuscular haemoglobin concentration; RDW - red blood cell distribution width; PLT - platelet count; MPV - mean platelet volume.

Table 3. Frequency (\%) of findings in the erythrogram and platelet count of young obese and senior obese dogs.

\begin{tabular}{lcccccc}
\hline & \multicolumn{3}{c}{$\begin{array}{c}\text { G1 (30 dogs) } \\
\text { (2 to 8 years) }\end{array}$} & & \multicolumn{3}{c}{$\begin{array}{c}\text { G2 }(29 \text { dogs }) \\
\text { ( }>8 \text { years })\end{array}$} \\
\cline { 2 - 7 } Indicator & $\begin{array}{c}\text { Decreased } \\
\%(\mathrm{~N})\end{array}$ & $\begin{array}{c}\text { Normal } \\
\%(\mathrm{~N})\end{array}$ & $\begin{array}{c}\text { Increased } \\
\%(\mathrm{~N})\end{array}$ & $\begin{array}{c}\text { Decreased } \\
\%(\mathrm{~N})\end{array}$ & $\begin{array}{c}\text { Normal } \\
\%(\mathrm{~N})\end{array}$ & $\begin{array}{c}\text { Increased } \\
\%(\mathrm{~N})\end{array}$ \\
\hline Haemoglobin $(\mathrm{g} / \mathrm{dl})$ & $0.00(0)^{\mathrm{b}}$ & $53.34(16)^{\mathrm{a}}$ & $46.66(14)^{\mathrm{a}}$ & $0.00(0)^{\mathrm{b}}$ & $58.63(17)^{\mathrm{a}}$ & $41.37(12)^{\mathrm{a}}$ \\
PCV $(\%)$ & $0.00(0)^{\mathrm{b}}$ & $56.66(17)^{\mathrm{a}}$ & $43.34(13)^{\mathrm{b}}$ & $0.00(0)^{\mathrm{b}}$ & $68.97(20)^{\mathrm{a}}$ & $31.03(9)^{\mathrm{b}}$ \\
RBC $\left(\times 10^{6} / \mu \mathrm{l}\right)$ & $0.00(0)^{\mathrm{b}}$ & $76.66(23)^{\mathrm{a}}$ & $23.34(7)^{\mathrm{b}}$ & $0.00(0)^{\mathrm{b}}$ & $72.41(21)^{\mathrm{a}}$ & $27.59(8)^{\mathrm{b}}$ \\
MCV $(\mathrm{fl})$ & $6.66(2)^{\mathrm{b}}$ & $93.34(28)^{\mathrm{a}}$ & $0.00(0)^{\mathrm{b}}$ & $17.25(5)^{\mathrm{b}}$ & $82.75(24)^{\mathrm{a}}$ & $0.00(0)^{\mathrm{b}}$ \\
MCHC $(\mathrm{g} / \mathrm{dl})$ & $3.33(1)^{\mathrm{b}}$ & $93.34(28)^{\mathrm{a}}$ & $3.33(1)^{\mathrm{b}}$ & $3.45(1)^{\mathrm{b}}$ & $93.10(27)^{\mathrm{a}}$ & $3.45(1)^{\mathrm{b}}$ \\
RDW $(\%)$ & $76.66(23)^{\mathrm{a}}$ & $23.34(7)^{\mathrm{b}}$ & $0.00(0)^{\mathrm{b}}$ & $44.82(13)^{\mathrm{a}}$ & $55.18(16)^{\mathrm{a}}$ & $0.00(0)^{\mathrm{b}}$ \\
PLT $\left(\times 10^{3} \mu / \mathrm{l}\right)$ & $16.66(5)^{\mathrm{b}}$ & $80.00(24)^{\mathrm{a}}$ & $3.34(1)^{\mathrm{b}}$ & $24.14(7)^{\mathrm{b}}$ & $75.86(22)^{\mathrm{a}}$ & $0.00(0)^{\mathrm{b}}$ \\
MPV $(\mathrm{fl})$ & $16.66(5)^{\mathrm{b}}$ & $83.34(25)^{\mathrm{a}}$ & $0.00(0)^{\mathrm{b}}$ & $24.14(0)^{\mathrm{b}}$ & $75.86(29)^{\mathrm{a}}$ & $0.00(0)^{\mathrm{b}}$ \\
\hline
\end{tabular}

(a,b) Different superscripts in rows indicate a significant difference $(P<0.05)$.

N - number of dogs; G1 - Group 1; G2 - Group 2; PCV - packed cell volume; RBC - red blood cell count; MCV - mean corpuscular volume; MCHC - mean corpuscular haemoglobin concentration; RDW - red blood cell distribution width; PLT - platelet count; MPV - mean platelet volume. 
Table 4. Values (mean \pm standard deviation) of the leukogram indicators of obese dogs by age group.

\begin{tabular}{lcrrrr}
\hline \multirow{2}{*}{ Indicator } & \multicolumn{2}{c}{$\begin{array}{c}\text { G1 (30 dogs) } \\
(2 \text { to } 8 \text { years })\end{array}$} & \multicolumn{2}{c}{$\begin{array}{c}\text { G2 }(29 \text { dogs }) \\
(>8 \text { years })\end{array}$} & \multirow{2}{*}{$\begin{array}{c}\text { Reference } \\
\text { value }\end{array}$} \\
\cline { 2 - 5 } & \multicolumn{1}{c}{ Mean } & \multicolumn{1}{c}{ SD } & \multicolumn{1}{c}{ Mean } & \multicolumn{1}{c}{ SD } & \\
\hline WBC $(/ \mu 1)$ & $12947^{\text {a }}$ & 3978 & $14476^{\text {a }}$ & 5596 & $6000-17000^{*}$ \\
Band neutrophils $(/ \mu 1)$ & $694^{\mathrm{a}}$ & 641 & $433^{\mathrm{a}}$ & 245 & $0-300^{*}$ \\
Segmented neutrophils $(/ \mu \mathrm{l})$ & $9153^{\mathrm{a}}$ & 3333 & $10201^{\mathrm{a}}$ & 4721 & $3000-11200^{*}$ \\
Total neutrophils $(/ \mu \mathrm{l})$ & $9847^{\mathrm{a}}$ & 3495 & $10634^{\mathrm{a}}$ & 4872 & $3000-11500^{*}$ \\
Eosinophils $(/ \mu \mathrm{l})$ & $801^{\mathrm{a}}$ & 657 & $1121^{\mathrm{a}}$ & 980 & $100-1250^{*}$ \\
Monocytes $(/ \mu \mathrm{l})$ & $434^{\mathrm{a}}$ & 273 & $672^{\mathrm{a}}$ & 460 & $150-1350^{*}$ \\
Lymphocytes $(/ \mu \mathrm{l})$ & $1900^{\mathrm{a}}$ & 887 & $2049^{\mathrm{a}}$ & 734 & $1000-4800^{*}$ \\
\hline
\end{tabular}

$(a, b)$ Different superscripts in rows indicate a significant difference $(P<0.05)$.

SD - standard deviation; WBC - white blood cell count.

*Weiss and Wardrop (2010).

Table 5. Values (mean \pm standard deviation) of the leukogram indicators of obese dogs by age group and sex.

\begin{tabular}{|c|c|c|c|c|c|}
\hline \multirow[t]{2}{*}{ Indicator } & \multirow[t]{2}{*}{ Sex } & \multicolumn{2}{|c|}{$\begin{array}{l}\text { G } 1 \text { ( } 30 \text { dogs }) \\
\text { ( } 2 \text { to } 8 \text { years })\end{array}$} & \multicolumn{2}{|c|}{$\begin{array}{c}\text { G } 2(29 \text { dogs }) \\
(>8 \text { years })\end{array}$} \\
\hline & & Mean & SD & Mean & SD \\
\hline \multirow{2}{*}{ WBC $(/ \mu 1)$} & M & $12770^{\mathrm{aA}}$ & 3325 & $16100^{\mathrm{aA}}$ & 8512 \\
\hline & $\mathrm{F}$ & $13035^{\mathrm{aA}}$ & 4347 & $13959^{\mathrm{aA}}$ & 4461 \\
\hline \multirow{2}{*}{ Band neutrophils $(/ \mu 1)$} & $\mathrm{M}$ & $769^{\mathrm{aA}}$ & 721 & $507^{\mathrm{aA}}$ & 316 \\
\hline & $\mathrm{F}$ & $657^{\mathrm{aA}}$ & 614 & $410^{\mathrm{aA}}$ & 222 \\
\hline \multirow{2}{*}{ Segmented neutrophils $(/ \mu 1)$} & $\mathrm{M}$ & $9197^{\mathrm{aA}}$ & 2865 & $10526^{\mathrm{aA}}$ & 6812 \\
\hline & $\mathrm{F}$ & $9131^{\mathrm{aA}}$ & 3614 & $10098^{\mathrm{aA}}$ & 4052 \\
\hline \multirow{2}{*}{ Total neutrophils $(/ \mu \mathrm{l})$} & $\mathrm{M}$ & $9966^{\mathrm{aA}}$ & 2945 & $11033^{\mathrm{aA}}$ & 7029 \\
\hline & $\mathrm{F}$ & $9788^{\mathrm{aA}}$ & 3811 & $10508^{\mathrm{aA}}$ & 4179 \\
\hline \multirow{2}{*}{ Eosinophils $(/ \mu \mathrm{l})$} & $\mathrm{M}$ & $628^{\mathrm{aB}}$ & 379 & $2260^{\mathrm{aA}}$ & 1363 \\
\hline & $\mathrm{F}$ & $888^{\mathrm{aA}}$ & 754 & $758^{\mathrm{bA}}$ & 427 \\
\hline \multirow{2}{*}{ Monocytes $(/ \mu \mathrm{l})$} & $\mathrm{M}$ & $448^{\mathrm{aA}}$ & 268 & $853^{\mathrm{aA}}$ & 698 \\
\hline & $\mathrm{F}$ & $428^{\mathrm{aA}}$ & 282 & $614^{\mathrm{aA}}$ & 359 \\
\hline \multirow{2}{*}{ Lymphocytes $(/ \mu \mathrm{l})$} & $\mathrm{M}$ & $1750^{\mathrm{aA}}$ & 695 & $1955^{\mathrm{aA}}$ & 899 \\
\hline & $\mathrm{F}$ & $1975^{\mathrm{aA}}$ & 977 & $2079^{\mathrm{aA}}$ & 695 \\
\hline
\end{tabular}

(A,B) Different upper-case superscripts in column indicate a significant difference between age groups $(P<0.05)$.

$(\mathrm{a}, \mathrm{b})$ Different lower-case superscripts in rows indicate a significant difference between males and females $(P<0.05)$.

SD - standard deviation; WBC - white blood cell count.

In an analysis of age groups and sexes (Table 5), only eosinophils presented a difference between the groups, with the average of the males in G2 exceeding that of the females in $\mathrm{G} 2$ and of the males in $\mathrm{G} 1(P<0.05)$.

An analysis of the frequency of findings of leukogram indices (Table 6) revealed that most of the dogs in G1 and G2 presented values of leukocytes, total neutrophils, segmented neutrophils, monocytes, lymphocytes and eosinophils within the limits of normality. The number of eosinophils was increased in $34.48 \%$ of the dogs in G2, while band neutrophils were augmented in $90.00 \%$ of the animals of G1 and in $68.96 \%$ of G2. 
Table 6. Frequency (\%) of findings in the leukogram indicators and platelet count of young obese and senior obese dogs

\begin{tabular}{|c|c|c|c|c|c|c|}
\hline \multirow{2}{*}{ Indicator } & \multicolumn{3}{|c|}{$\begin{array}{l}\text { Young obese dogs } \\
\text { ( } 2 \_8 \text { years) }\end{array}$} & \multicolumn{3}{|c|}{$\begin{array}{c}\text { Senior obese dogs } \\
\quad(>8 \text { years })\end{array}$} \\
\hline & $\begin{array}{c}\text { Decreased } \\
\%\left(\mathrm{~N}^{*}\right)\end{array}$ & $\begin{array}{l}\text { Normal } \\
\%\left(\mathrm{~N}^{*}\right)\end{array}$ & $\begin{array}{l}\text { Increased } \\
\%\left(\mathrm{~N}^{*}\right)\end{array}$ & $\begin{array}{c}\text { Decreased } \\
\%\left(\mathrm{~N}^{*}\right)\end{array}$ & $\begin{array}{l}\text { Normal } \\
\%\left(\mathrm{~N}^{*}\right)\end{array}$ & $\begin{array}{c}\text { Increased } \\
\%\left(\mathrm{~N}^{*}\right)\end{array}$ \\
\hline $\begin{array}{l}\text { WBC } \\
\text { Band }\end{array}$ & $3.34(1)^{\mathrm{b}}$ & $76.66(23)^{\mathrm{a}}$ & $20.00(6)^{b}$ & $0.00(0)^{\mathrm{b}}$ & $79.32(23)^{\mathrm{a}}$ & $20.68(6)^{b}$ \\
\hline $\begin{array}{l}\text { neutrophils }(/ \mu \mathrm{l}) \\
\text { Segmented }\end{array}$ & $0.00(0)^{\mathrm{b}}$ & $10.00(3)^{b}$ & $90.00(27)^{\mathrm{a}}$ & $0.00(0)^{\mathrm{c}}$ & $31.04(9)^{b}$ & $68.96(20)^{\mathrm{a}}$ \\
\hline neutrophils $(/ \mu \mathrm{l})$ & $0.00(0)^{\mathrm{b}}$ & $83.34(25)^{\mathrm{a}}$ & $16.66(5)^{b}$ & $0.00(0)^{b}$ & $75.86(22)^{\mathrm{a}}$ & $24.14(7)^{b}$ \\
\hline Total neutrophils & $0.00(0)^{\mathrm{b}}$ & $73.34(22)^{\mathrm{a}}$ & $26.66(8)^{b}$ & $0.00(0)^{\mathrm{b}}$ & $72.41(21)^{\mathrm{a}}$ & $27.59(8)^{b}$ \\
\hline Eosinophils & $3.34(1)^{\mathrm{b}}$ & $76.66(23)^{a}$ & $20.00(6)^{b}$ & $0.00(0)^{\mathrm{b}}$ & $65.52(19)^{\mathrm{a}}$ & $34.48(10)^{b}$ \\
\hline Lymphocytes & $16.66(5)^{b}$ & $80.00(24)^{a}$ & $3.34(1)^{\mathrm{b}}$ & $3.45(1)^{\mathrm{b}}$ & $96.55(28)^{a}$ & $0.00(0)^{\mathrm{b}}$ \\
\hline Monocytes & $20.00(6)^{b}$ & $80.00(24)^{\mathrm{a}}$ & $0.00(0)^{\mathrm{b}}$ & $6.89(2)^{\mathrm{b}}$ & $82.75(24)^{\mathrm{a}}$ & $10.36(3)^{b}$ \\
\hline
\end{tabular}

$(\mathrm{a}, \mathrm{b}, \mathrm{c})$ Different superscripts in rows indicate a significant difference $(P<0.05)$.

$\mathrm{N}$ - number of dogs; WBC - white blood cell count.

\section{Discussion}

Although the literature cites the occurrence of absolute anaemia in senior dogs as a common finding due to the transformation of yellow bone marrow into fibrous white bone marrow, making its expansion difficult and slow (Shock et al. 1963; Moiser 1989; Lopes et al. 2007), anaemia was not detected in the dogs of this study. Some animals in G2 presented polycythaemia (Table 3), which has also been reported as an important finding in older dogs due to dehydration which is common in this age group (Lopes et al. 2007).

The MCV and MCHC are RBC indices used to evaluate anaemia morphologically (Lopes et al. 2007), however, they may be altered while not showing anaemia. The age, breed and castration can influence these indices (Lawrence et al. 2013). This was observed in the animals of this study, which, although not presenting anaemia, showed some slight changes in these indices (Table 3).

The RDW is a measurement of anisocytosis, a condition in which the red blood cells are of unequal size. This is a good indicator to differentiate anaemia in which the red blood cell population is homogeneous (chronic diseases) from anaemia in which this population is heterogeneous (iron-deficiency anaemia) (Matos et al. 2008). The two groups showed lower RDW than the mean reference values (Table 1). The finding was that $76.66 \%$ of the dogs in G1 and $44.82 \%$ in G2 presented RDW below the reference values (Table 3), moreover, in most of the animals that showed decreased RDW, the value was close to the minimum reference value adopted here. Nevertheless, factors such as chronic inflammation, inefficient production of erythropoietin and congestive heart disease may influence the reduction of RDW (Felker et al. 2004; Tang and Katz 2006). We believe some of these factors may have influenced the result.

The MPV measures macrocytosis and microcytosis in platelets and is only meaningful when increased (Walker 2007). None of the animals presented this alteration.

In a study of senior dogs, Fukuda et al. (1989) found augmented haemoglobin concentration, PCV and RDW. The MCV, MCHC and mean corpuscular haemoglobin $(\mathrm{MCH})$ did not change as the dogs progressed in age. Strasser et al. (1993) also observed an increase in haemoglobin and haematocrit count, and a decrease in the platelet count in senior animals, but no change in the haemocyte count. Lawrence et al. (2013) observed 
increased erythrocytes, haemoglobin, $\mathrm{MCV}$ and $\mathrm{MCH}$ in dogs up to 4 years old, followed by gradual reduction of these indices till up to 12 years. The same authors believe this may occur in response to decreased erythropoiesis over the years due to decreased erythropoietin production and also a greater propensity for inflammatory diseases that occur with aging. To some extent, this study supports the findings of Lowseth et al. (1990), who found no haematological changes in senior dogs.

With respect to obesity, Harishankar et al. (2011) studied obese mice and found that thrombocytopaenia was the only alteration, although it was not found in the present study. Brunetto (2010) stated that obesity leads to a mild and chronic inflammatory condition characterized by increased serum concentrations of adipocytokines, leptin, TNF- $\alpha$ and IL6. Therefore, one could expect to find leukocytosis due to increased lymphopoiesis and granulopoiesis processes, since the former is induced by interleukins and interferons, and the latter by interleukins. Moreover, when neutrophils are activated, they secrete cytokines such as the tumour necrosis factor (TNF), further stimulating cell production (Lopes et al. 2007). However, this study found total leukocytes, neutrophils, monocytes, lymphocytes and eosinophils within the physiological limits, with only an augmented number of band neutrophils, characterizing left shift neutrophils (LSN) (Lopes et al. 2007). According to these authors, augmented release of immature neutrophils from bone marrow to circulating blood occurs when the demand for neutrophils to tissues increases, or in cases of myelogenous leukaemia or acute or chronic myelomonocytic leukaemia. Probably the increase of band neutrophils, in both groups, occurred due to an increase of adipocytes, IL-6, TNF- $\alpha$ and others pro-inflammatory cytokines that are released by the adipose tissue (Coppack 2001; Trayhurn and Beattie 2001; Trayhurn and Wood 2004; Trayhurn 2005). Higher infiltration and accumulation of macrophages in the adipose tissue may be observed in obese individuals, which might explain the increase of IL-6 and TNF- $\alpha$ expression during the expansion of this tissue (Weisberg et al 2003). This hypothesis was also put forward by German et al. (2009), who found that obese dogs presented the mean leukocyte count at the upper limit of the reference interval, and that after weight loss, these cells decreased significantly.

Lawrence et al. (2013) observed that age had a variable effect on white cell indicators, with decreased lymphocytes in young and middle-aged dogs. In older dogs, there was a relative increase of neutrophils, monocytes, and a lower increase of eosinophils and lymphocytes. The authors attribute this increase to possible inflammation that occurs most frequently at this age.

The evaluation of the concentrations of IL- 6 and TNF- $\alpha$ in both groups would be of great value to better understand this increase in neutrophil concentrations, unfortunately we could not confirm that the adipose tissue could be stimulating this haematological alteration.

Although the mean eosinophil count in G2 remained within the normal range (Table 4), the male dogs in this group presented a higher average than the reference value (Table 5). Eosinophilia can be triggered by chronic tissue loss, allergic reactions, parasitism, hypoadrenocorticism, drug therapy, breed-related predisposition, purulent disorders, and reactive eosinophilia (Lopes et al. 2007), however, due to the general clinical evaluation and complementary examinations, none of these alterations were identified in the dogs of this study. Most of eosinophilia seems to be correlated to eosinophil anti-inflammatories function, however, according to Stockham and Scott (2011), a discrete and persistent eosinophilia could be observed in clinically healthy mammals without the detection of either parasitism or another subclinical disease. However, none of these factors was confirmed in the clinical examination of the males in G2, since the animals presented no clinical symptoms that could suggest the need for a more thorough investigation. Since $65.52 \%$ of dogs in G2 showed an eosinophil count within the physiological limits, the 
average in the males of this group may have been elevated by the presence in the group of animals with a score well above the reference values, probably due to a common subclinic inflammatory alteration in aged dogs (Lawrence et al. 2013).

The results of this study led to the conclusion that obese dogs, regardless of age and sex, do not show significant changes in erythrogram and platelet indicators, and that their leukocyte indicators may present discrete LSN without leukocytosis or neutrophilia. These findings may provide veterinarians with an effective tool to monitor senior dogs, where laboratory tests have become an essential and indispensable part of the evaluation of dogs' health.

\section{References}

Bastard JP, Maachi M, Lagathu C, Kim MJ, Caron M, Vidal H, Capeau J, Feve B 2006: Recent advances in the relationship between obesity, inflammation, and insulin resistance. Eur Cytokine Netw 17: 4-12

Biase NG, Ferreira DF 2009: Comparações múltiplas e testes simultâneos para parâmetros binomiais de $\mathrm{K}$ populações independentes (Multiple comparisons and simultaneous tests for binomial parameters of $\mathrm{K}$ independent populations). RBB 27: 301-323

Brunetto MA 2010: Perda de peso, indicadores do metabolismo de carboidratos e produção e citocinas em cães (Weight loss, indicators of carbohydrate metabolism and production and cytokines in dogs). São Paulo. 81f. Tese (Doutorado em Clínica Médica) - Faculdade de Ciências Agrárias e Veterinárias, Universidade Estadual Paulista, Campus Jaboticabal, São Paulo. https://repositorio.unesp.br/handle/11449/101229 (Accessed: September 10, 2017)

Carciofi AC, Gonçalves KNV, Vasconcelos RS, Bazolli RS, Brunetto MA, Prada F 2005: A weight loss protocol and owners participation in the treatment of canine obesity. Cienc Rural 35: 1331-1338

Carrijo JR, Souza AL 2009: Estudo comparativo da qualidade de vida de cães geriátricos de Bauru e São Bernardo do Campo - SP e Campo Grande - MS (Comparative study of the quality of life of geriatric dogs from Bauru and São Bernardo do Campo - SP and Campo Grande - MS). Ver Medvep 7: 295-301

Coppack SW 2001: Pro-inflammatory cytokines and adipose tissue. Proc Nutr Soc 60: 349-356

Diez M, Nguyen P 2006: Obesity: epidemiology, pathophysiology and management of the obese dog. In: Pibot P, Biourge V, Elliott DA: Encyclopedia of Canine Clinical Nutrition. Paris, Aniwa SAS, pp. 2-57

Faria PFF, Araújo DF, Blanco BS 2005: Glicemia em cães obesos e senis (Glycaemia in obese and elderly dogs). Acta Sci Vet 33: 47-50

Felker GM, Adams Jr KF, Gattis WA, O’ Connor CM 2004: Anemia as a risk factor and terapeutic target in heart failure. JACC 44: 959-966

Felker GM, Allen LA, Pocock SJ, Shaw LK, McMurray JJ, Pfeffer MA, Swedberg K, Wang D, Yusuf S, Michelson EL, Ganger CB 2007. Red cell distribution width as a novel prognostic marker in heart failure: data from the CHARM Program and the Duke Data Bank. JACC 50: 40-47

Figueiredo C 2005: Geriatria clínica dos caninos e felinos (Clinical Geriatrics of Canine and Feline) Rio de Janeiro: Guanabara Koogan S.A. 112 p.

Fukuda S, Hawashima N, Iida H, Aoki J, Tokita K 1989: Age dependency of hematological values and concentrations of serum biochemical constituents in normal beagles from 1 to 14 years of age. Jpn J Vet Res 51: $636-641$

German AJ 2006: The growing problem of obesity in dogs and cats. J Nutr 136: 1940S-1946S

German AJ, Hervera M, Hunter L, Holden SL, Morris PJ, Biourge V, Trayhurn P 2009: Improvement in insulin resistance a and reduction in plasma inflammatory adipokines after weight loss in obese dogs. Domest Anim Endocrinol 37: 214-226

Harishankar N, Kuman PV, Sesikeran B, Giridharan N 2011: Obesity associated pathophysiological \& histological changes in WNIN obese mutant rats. Indian J Med Res 134: 330-340

Inadera H 2008: The usefulness of circulating adipokine levels for the assessment of

obesity-related health problems. Int J Med Sci 5: 248-262

Jericó MM, Scheffer KC 2002: Aspectos epidemiológicos dos cães obesos na cidade de São Paulo (Epidemiological aspects of obese dogs in the city of São Paulo). Revista Clínica Veterinária 37: 25-29

Kienzle E, Bergler R, Mandernach A 1998: A comparison of the feeding behavior and the human-animal relationship in owners of normal and obese dogs. J. Nutr 128: 2779S-2782S

Laflamme DP 1997: Development and validation of a body condition score system for dogs. Canine Pract 22: $10-15$

Laflamme DP 2006: Understanding and managing obesity in dogs and cats. Vet Clin North Am Small Anim Pract 36: $1283-1295$

Lazzarotto JJ 1999: Relação entre aspectos nutricionais e obesidade em pequenos animais (Relation between nutritional aspects and obesity in small animals). Revista Universidade de Alfenas 5: 33-35

Lawrence J, Chang YM, Szladovits B, Davison LJ, Garden, AO 2013: Breed-specific haematological phenotypes 
in the dog: a natural resource for the genetic dissection of haematological parameters in a mammalian species. PLOS One 8, e81288.

Lopes ST dos A, Biondo AW, Dos Santos AP 2007: Manual de patologia clínica veterinária. $3^{\text {rd }}$ edn. Santa Maria: Departamento de Clínica de Pequenos Animais, Universidade Federal de Santa Maria, 144 p.

Lowseth LA, Gillet NA, Gerlach RF, Muggenburg BA 1990: The effects of aging on hematology and serum chemistry values in the beagle dog. Vet Clin Pathol 19: 12-19

Markwell PJ, Edney ATB 1996: The obese animal. In: Wills J, Kelly N: Manual of Companion Animal Nutrition \& Feeding, Iowa: BSAVA, pp. 108-115

Matos JF, Dusse LMS, Stubbert RV, Lages GFG, Carvalho MG 2008: Índice de anisocitose eritrocitária (RDW): diferenciação das anemias microcíticas e hipocrômicas (Erythrocyte anisocyte index (RDW): differentiation of microcytic and hypochromic anaemias). Rev Bras Hematol Hemoter 30: 120-123

Matos MS, Matos PF 1988: Laboratório clínico médico-veterinário. $2^{\text {nd }}$ edn. Rio de Janeiro: Atheneu, $238 \mathrm{p}$.

McGreevy PD, Thomson PC, Pride C, Fawcett A, Grassi T, Jones B 2005: Prevalence of obesity in dogs examined by Australian Veterinary Practices and the risk factors involved. Vet Rec 156: 695-702

Moiser EJ 1989: Effect of aging on body systems of the dog. Vet Clin North Am Small Anim Pract 19: 01-11

Shock NW, Watkin DM, Yiengst BS, Norris AH, Gaffney GW, Gregerman RE, Falzone JA 1963: Age differences in the water content of the body as related to basal oxygen differences in the water content of the body as related to basal oxygen consumption in males. J Gerontol 18: 1-8

Strasser A, Niedermuller, H, Hofecker G, Laber G 1993: The Effect of aging on laboratory values in dogs. J Vet Med A 40: 720-730

Tang YD, Katz SD 2006: Anemia in chronic heart failure: prevalence, etiology, clinical correlates, and treatment options. Circulation 113: 2454-2461

Trayhurn P 2005: Endocrine and signalling role of adipose tissue: new perspectives on fat. Acta Physiol Scand 84: $285-293$

Trayhurn P, Beattie JH 2001: Physiological role of adipose tissue: white adipose tissue as an endocrine and secretory organ. Proc Nutr Soc 60: 329-339

Trayhurn P, Wood IS 2004: Adipokines: inflammation and the pleiotropic role of white adipose tissue. Br J Nutr 92: $347-355$

Walker D 2007: Peripheral blood smears. In: Cowell R, Tyler R, Meinkoth J. Diagnostic, cytology and hematology of the dog and cat. $3^{\text {rd }}$ edn. Mosby, St. Louis, pp. 254-283

Weisberg SP, McCann D, Desai M, Rosenbaum M, Leibel RL, Ferrante AW Jr 2003: Obesity is associated with macrophage accumulation in adipose tissue. J Clin Invest 112: 1796-1808

Weiss DJ, Wardrop JK 2010: Schalm's Veterinary Hematology. $6^{\text {th }}$ edn. Ames-USA: Wiley- Blacwell Publication, Chapter 104, pp. 799-810

Wolfsheimer KJ 1994: Obesity in dogs. Comp Cont Educ Pract Vet 16: 981-997

Zvorc Z, Rafaj RB, Kules J, Mrljak V 2010: Erythrocyte and platelet indices in babesiosis of dogs. Vet Arhiv 80: $259-267$ 